\title{
Molecular Taxonomy, Population Genetics and Reproductive Studies of the Jellyfish (Scyphozoa) in Selected Areas of Malaysian Waters
}

\author{
Maghsoudlou Elham ${ }^{1 *}$, Khairun Yahya ${ }^{1,2}$ Mohd Nor Siti Azizah $^{1,2}$ \\ ${ }^{1}$ Centre for Marine \& Coastal Studies (CEMACS) Universiti Sains Malaysia, Malaysia \\ ${ }^{2}$ School of Biological Sciences, Universiti Sains Malaysia, Malaysia
}

Submission:December 02, 2017; Published: January 18, 2018

*Corresponding author: Maghsoudlou Elham, Centre for Marine \& Coastal Studies (CEMACS) Universiti Sains Malaysia, Penang, 11800 Minden, Malaysia, Tel: +604-6048852750; Fax: +6048852751; Email: maghsoudlou.elham@gmail.com

\section{Mini Review}

This study employed molecular and reproductive biology approaches to investigate the jellyfish, along the coasts of Malaysia. The molecular approach was conducted to resolve the taxonomic and systematics as well as population genetics of several species within this group. In the first part of this study, a total of 445 individuals were sampled from six locations. The barcoding method was employed using the standard region of cytochrome oxidae subunit 1 (COI) gene in complement with 16S rRNA (700bp) genes for species identification and discovery. Phylogenetic trees were constructed using MEGA 5.0 software and Kimura 2-parameter was used to test reliability. Subsequently six species belonging to three families were identified.

These were Chrysaora sp. family Pelagiidae; Rhopilema escluntum and R. hispidum family Rhizostomatidae and Phyllorhiza punctata, Phyllorhiza sp.2, Phyllorhiza sp.3 family Mastigiidae. Based on the present data a closer relationship was observed between Phyllorhiza and Rhopilema in comparison to Chrysaora. Genus Phyllorhiza was detected as invasive and genus Rhopilema, an edible jellyfish, had the potential to be developed as an economic product as is practiced in Japan and China.

In addition, these molecular markers identified the likelihood of invasive species as well as cryptic species occurrences in the Malaysian waters. The ctenophor Phyllorhiza spp. is native to Australia but was suspected to have already established its presence in the Peninsular Malaysian waters based on morphologically identified samples $[1,2]$. The genetic data obtained in this study unfortunately has confirmed that the situation is true. El-Serehy and Al-Rasheid suggested migration of marine fauna (planktonic organism, adults and planktonic larvae of benthic forms) may occur by positive transport of water currents and by other organisms and man; and by active migration for large animals. As well as, natural transport from donor regions or by anthropogenic means (shipping, aquarium trade, etc.) are another ways that maybe led to Phyllorhiza which reported to be indigenous to the tropical Western Pacific Ocean $[3,4]$ and has had attendant ecological and economic effects on recipient regions like other invasive gelatinous zooplankton successfully arrived to Malaysia. In addition, two previously undocumented Phyllorhiza species in the Gen Bank, Phyllorhiza sp. 2 and Phyllorhiza sp. 3 were observed in the East coast of Peninsular Malaysia illustrating the presence of cryptic species.

The molecular markers also permitted the geographic distributions to be elucidated. The COI and 16S rRNA genes were shown to be efficient and suitable barcoding markers for identifying specimens of Malaysian jellyfish species and population level. There is no compelling evidence to indicate that individual colour morphs represent independent evolutionary lineages and the hypothesis that explained different morphs as evidence of different species breakdown when these specimens were considered. On the other hand, different morphotypes of Chrysaora, Phyllorhiza punctata and Phyllorhiza sp.2 formed individual monophyletic species.

These results are comparable with Gershwin [5] observations that members of the species, Aurelia labiata are vastly different in morphology but were genetically indistinguishable. In a similar study conducted in the coastal waters of the Atlantic Ocean. Bayha found different morphotypes of Chrysaora were genetically identical. Closer to home, three species of Chrysaora was previously thought to exist in the coastal waters of Penang Island by Sim [1] based on morphological differences. However, the molecular data generated in this study indicated that different morphotypes of this species belong to a single species of Chrysaora. Phylogenetic and population genetic analysis revealed that no genetic structuring among populations was observed in Malaysia and the local populations were a 
genetically isolated taxonomic entity from other Chrysaora spp. documented in Gen Bank inhabiting other locations in the world. Thus, colour alone is not sufficient for species differentiation.

These results are comparable with studies by Bolton \& Graham [6] and Galil et al. [7] had reported the same range of colour variation morphs for P. punctata. The current study supported the theory that in medusae, increasing taxonomic levels was directly correlated to genetic divergence but only within species level. At higher levels, there was a great deal of overlap for example among genera and among families. This is in agreement to the investigation by Ortman [8] who that reported different genes resolved different level of taxonomic organization and explained mtCOI resolved fine-scale among some species while $28 \mathrm{~S}$ and ITS are suitable for identification at the family and phylum level.

Chrysaora sp. was found to be the dominant species in jellyfish blooms along the coasts of Penang Island in agreement with previous studies in this area [1] and also in the Straits of Malacca [2]. Thus, it was chosen as a priority candidate species to answering several aspects of reproductive biology questions that are important for management strategies. In addition, the rate of predation in this species is high and the polyps of this species also have the ability to survive and asexually propagate even in hypotoxic condition [9].

The blooms of this species have led to decrease in fisheries stock and also seriously affected the tourist industry [10] which therefore requires urgent management. The spawning and the peak of the reproductive season in Chrysaora sp. were detected in July. Rainfall did not seem to play an important role in the reproductive cycle of this tropical jellyfish.

Chrysaora sp. is consists of male and female in separate individuals. The sex ratio can be very unequal and may fluctuate during different periods of the year. Male was found to be predominant in the population. Pope [11] observed medusae population of Craspedcusta sowerbi in 1977 in North America was predominantly female while during 2001 and 2002 was male. It is may affected by sample sizes and time of the Season while Lucas \& Lawes [12] and Pitt \& Kingsford [13] recorded a 1:1 ratio for A. aurita and Catostylus mseeosaicus within a period of one year.

This reproductive biology investigation of Chrysaora sp. has provided a good reference for other marine invertebrates that spawn in the water column, i.e. these strategies are not restricted to jellyfish. Thus, the data has wide potential application and is certainly an important contribution to the reproductive study of gelatinous zooplankton. Due to its invasiveness, the jellyfish can adversely affect the flora and fauna of the native aquatic communities by disturbing the balance of the food web, nutrient dynamics and biodiversity.

This study has thus provided beneficial data for the taxonomy and reproductive biology of jellyfish in tropical waters and the results of the current study will be important for future studies in the field of ecology. In Malaysia the jellyfish is hardly of any economic value at the moment, thus expanding the jellyfish product industry in Peninsular Malaysia will not only be good for the economy but will help to decrease jellyfish population sizes.

The identification of new species in the Malaysian waters strongly suggests that the number of valid species documented in the literature thus far, is likely to be an underestimate. Therefore, future studies should include more locations of the Malaysian waters with more variable markers (nuclear introns or microsatellite, etc.) to assess more precisely the genetic differences and structure. The potential economic value of jellyfish species such as R. escluntum could be a target for aquaculture. Thus, this should spur more fundamental and systematic investigations on various aspects of the biology, ecology and reproduction of this species.

\section{References}

1. Sim YK, Khairun Y (2009) The monthly distribution and abundance of Jellyfish (Medusae) species in the coastals wateres of Penang National Park, Penang, Malaysia. Malaysia International Conference on the Marine Ecosystems Langkawi, Malaysia.

2. Chuah (2012) Species composition, abundance and distribution of jellyfish in the costal waters of strait of Malacca Master of Science, University Sains Malaysia, Malaysia.

3. Graham WM, Martin DL, Felder DL, Asper VL, Perry HM (2003) Ecological and economic implications of a tropical jellyfish invader in the Gulf of Mexico. Biological Invasions 5(1-2): 53-69.

4. Graham WM, Bayha KM (2007) Biological invasions by marine jellyfish. Biological Invasions 239-255.

5. Gershwin L (2001) Systematics and biogeography of the jellyfish Aurelia labiata (Cnidaria: Scyphozoa). Biol Bull 201(1): 104-119.

6. Bolton TF, Graham WM (2004) Morphological variation among populations of an invasive jellyfish. Marine Ecology Progress Series 278: $125-139$.

7. Galil BS, Shoval L, Goren M (2009) Phyllorhiza punctata von Lendenfeld, 1884 (Scyphozoa: Rhizostomeae: Mastigiidae) reappeared off the Mediterranean coast of Israel. Aquatic Invasions 4(3): 481-483.

8. Ortman BD (2008) DNA barcoding the medusozoa and ctenophora. $\mathrm{PhD}$ Thesis, University of Connecticut, Storrs, Connecticut, USA.

9. Condon RH, Decker MB, Purcell JE (2001) Effects of low dissolved oxygen on survival and asexual reproduction of scyphozoan polyps (Chrysaora quinquecirrha). Hydrobiologia 451(1-3): 89-95.

10. Purcell JE, Uye SI, Lo WT (2007) Anthropogenic causes of jellyfish blooms and their direct consequences for humans: a review. Marine Ecology Progress Series 350: 153-174.

11. Pope LG (2007) Sexual dimorphism and symmetry variation in the freshwater jellyfish, Craspedacusta sowerbii (Lankester). Master of Science Thesis, Southern Illinois University Carbondale, USA.

12. Lucas CH, Lawes S (1998) Sexual reproduction of the scyphomedusa Aurelia aurita in relation to temperature and variable food supply. Marine Biology 131(4): 629-638.

13. Pitt KA, Kingsford MJ (2000) Reproductive biology of the edible jellyfish Catostylus mosaicus (Rhizostomeae). Marine Biology 137(56): 791-799. 
CC This work is licensed under Creative (C) Commons Attribution 4.0 Licens DOI: 10.19080/OFOAJ.2018.05.555674
Your next submission with Juniper Publishers will reach you the below assets

- Quality Editorial service

- Swift Peer Review

- Reprints availability

- E-prints Service

- Manuscript Podcast for convenient understanding

- Global attainment for your research

- Manuscript accessibility in different formats

(Pdf, E-pub, Full Text, Audio)

- Unceasing customer service

Track the below URL for one-step submission https://juniperpublishers.com/online-submission.php 